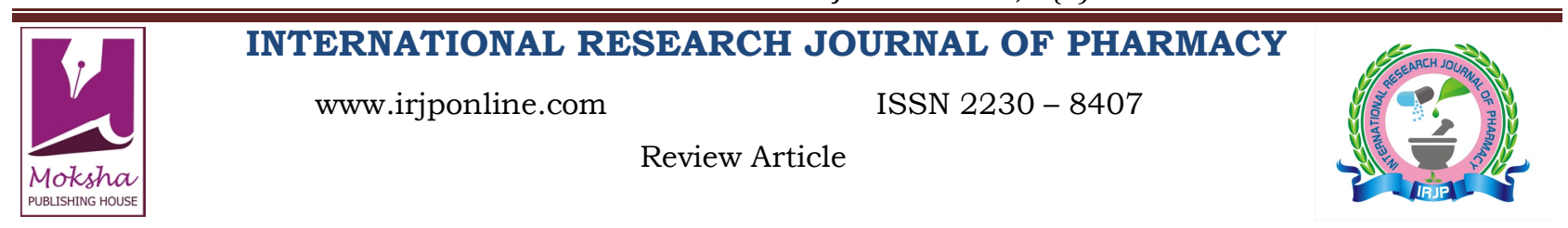

\title{
CRONOBACTER SAKAZAKII: AN EMERGING CONTAMINANT IN PEDIATRIC INFANT MILK FORMULA
}

Adeel Arsalan*, Zubair Anwar, Iqbal Ahmad, Zufi Shad, Sadia Ahmed

Institute of Pharmaceutical Sciences, Baqai Medical University, Toll Plaza, Super Highway, Gadap Road, Karachi, Pakistan

Email: adeelarsalan@hotmail.com

Article Received on: 20/02/13 Revised on: 01/03/13 Approved for publication: 21/04/13

DOI: $10.7897 / 2230-8407.04403$

IRJP is an official publication of Moksha Publishing House. Website: www.mokshaph.com

(C) All rights reserved.

\section{ABSTRACT}

Cronobacter sakazakii (C. sakazakii) previously known as Enterobacter sakazakii is a motile, Gram-negative, non-sporing yellow pigmented rod, which belongs to lethal Enterobacteriaceae family. C. sakazakii is ubiquitously found in air, soil, floor drains, and dry product processing environment. It has been isolated from hospitals, clinical materials, and cutting fluids and is also present in cerebrospinal fluid (CSF), blood, sputum, throat, nose, stool, gut, skin, wounds, bone marrow, eye, ear and breast abscesses. C. sakazakii is a virulent pathogen and can adhere to silicon, latex, polycarbonate, and stainless steel. Therefore, Feeding-bottles or utensils used to prepare pediatric infant formula (PIF) should be thoroughly cleaned to diminish the development of biofilms, which could be the source of infections. Due to its virulence, C. sakazakii causes life threatening infections such as septicemia, necrotizing enterocolitis, bacteriamia and meningitis. Hence, the regulatory authorities such as Food and Drug Administration (FDA), Food and Agriculture Organization/World Health Organization (FAO/WHO), Centers for Disease Control and Prevention (CDC) and Health Canada strongly recommend breast-feeding over the bottle-feed to minimize the risk of infections caused by $C$. sakazakii.

Keywords: Cronobacter sakazakii; Pediatric infant formula; Contamination; Necrotizing enterocolitis; Meningitis

\section{INTRODUCTION}

Cronobacter sakazakii (C. sakazakii) is an emerging foodborne, motile, peritrichous, Gram-negative rods, non-sporeforming bacterium belonging to the Enterobacteriaceae family. It is an opportunistic human and food-borne pathogen previously known as yellow pigmented Enterobacter sakazakii. Farmer et al. mentioned the first used of the name E. sakazakii ${ }^{1}$ after the Japanese bacteriologist Riichi Sakazakii. Several genera and species of Enterobacteriaceae have been isolated from the reconstituted pediatric infant formula (PIF). C. sakazakii's physiological traits aid in its environmental survival, and give the ability to produce a yellow pigment that protects the cell against UV rays in sunlight. It also provides capsular and film barrier formation to assist in adherence to surfaces including other cell types, and its ability to resist desiccation during long dry periods ${ }^{2}$.

C. sakazakii has been of much concern in life-threatening bacterial infections especially in low birth-weight neonates and infants. The clinical isolates of the bacterium produce only slightly yellow pigmentation when cultured on nutrient agar at $37{ }^{\circ} \mathrm{C}$, but produce a non-diffusible yellow-gold pigment when incubated at room temperature. Pangalos in 1929 was the first to report that septicemia in an infant was caused by a yellow-pigmented coliform in tryptone soy agar TSA $^{3}$. Willis and Robinson reported $40-80 \%$ mortality rates among infected infants ${ }^{4}$. Neonatal infections have been associated with $C$. sakazakii colonization of the food preparation equipment such as brushes, blenders, and spoons ${ }^{5,6}$. Its contamination from the samples of commercially available dry PIF has been reported ${ }^{7-9}$. $C$. sakazakii is an opportunistic pathogen most commonly affecting immunocompromised patients and neonates ${ }^{4,10}$. Neonatal infections have been reported to be on rise via contact with $C$. sakazakii in the birth canal or through postbirth environmental sources ${ }^{11-13}$.

\section{Detection of Cronobacter sakazakii}

Steigerwalt and his co-workers have observed that the presence or absence of yellow pigmentation can distinguish between the two strains of Enterobacteriaceae family (Enterobacter cloacae and C. sakazakii) when these strains are cultured on tryptone soy agar (TSA) ${ }^{14}$. It was further reported that fermentation of D-sorbitol helps in the differentiation among different strains ${ }^{15}$. C. sakazakii can be identified by some traditional biochemical methods, but there is a need of isolation in pure culture from mixed contamination in PIF before identification can be carried out $^{16}$. Biochemical tests for the identification of C. sakazakii are shown in Table 1.

Currently, molecular detection methods such as polymerase chain reaction (PCR), real-time PCR, and immunoassays are commonly employed for its identification ${ }^{17}$. Sometimes even more advanced methods such as DNA microarray-based assays have been used for the detection of C. sakazakii ${ }^{18}$. In the investigation of PIF contamination, a combination of methods such as antibiograms, ribotyping, plasmid analysis, multilocus enzyme electrophoresis, and chromosomal restriction fragment analysis have been used ${ }^{19}$.

\section{Sources of contamination}

C. sakazakii has been isolated from floor drains, air, vacuum canister, broom bristles, room heater, electrical control box, transition socks, a clean-inplace valve, floor, and condensate in a dry product processing plant ${ }^{4}$. Van Os et al. have isolated C. sakazakii from grass silage in The Netherlands ${ }^{20}$. It has also been isolated from hospital air ${ }^{21}$, clinical materials $^{22,23}$, rats ${ }^{24}$, soil ${ }^{25}$, rhizosphere ${ }^{26}$, sediment and wetlands ${ }^{27}$, crude oil ${ }^{28}$ and cutting fluids ${ }^{29}$.

\section{Clinical Sources}

Farmer et al. have reported that most of the C. sakazakii isolates from infected patients originate from CSF, blood, sputum, throat, nose, stool, gut, skin, wounds, bone marrow, eye, ear and breast abscess ${ }^{1}$. Although C. sakazakii infections in vaginally born newborns have been suspected to originate from mother's birth canal, the presence of its infection in neonates born through caesarian section has questioned this hypothesis $8,30,31$. Moreover, often the fecal, vaginal, and 
cervical swabs of the mothers who delivered newborn with $C$. sakazakii were negative on colonization. Samples from the anus, skin, nose, umbilical cord, and outer ear of two infants on their day of the birth were the also negative as were the samples from outer ear, nose, umbilicus, and gastric aspirate of another newborn tested for C. sakazakii ${ }^{4}$.

\section{Contamination in milk and milk-products}

It has been reported the chances of microbial contamination are reduced by the use of sterile liquid formula instead of $\mathrm{PIF}^{30}$. C. sakazakii has been found in dry powdered foods including unopened non-fat dried milk. In one survey of the powdered foods, about $27 \%$ of the total 140 foods tested positive for $C$. sakazakii and the powdered infant foods had the highest frequency of contamination (34\%) followed by PIF (about 33\%) and milk-based products (about 31\%) ${ }^{33}$. In addition, It has been isolated from various non-PIF sources including dried baby food, cheese, dry food ingredients, rice, herbs, and spices ${ }^{2,32-35}$. It was isolated from the three food type of powdered infant food, PIF and milk-based products in $27.1 \%$ of samples ${ }^{33}$. Krieg and Holt stated that C. sakazakii was more prevalent in foods and the environment than in the clinical settings ${ }^{32}$.

\section{Contamination in PIF}

Contaminated PIF is a recognized source of C. sakazakii, which poses a serious risk of infection to newborn infants ${ }^{36-}$ 38. Two main routes by which $C$. sakazakii can enter the reconstituted PIF are known as intrinsic contamination either through contaminated ingredients added after drying or from the processing environment following drying and before packing; and/or through external contamination of the formula during reconstitution and handling (e.g. through poorly cleaned utensils) ${ }^{2}$. The level of $C$. sakazakii is ranged from 0.36 to $66 \mathrm{cfu} / 100 \mathrm{~g}$. The Food and Agriculture Organization of the United Nations (FAO)/ World Health Organization (WHO) has recommended bacterial counts for coliforms in PIF of less than $3 \mathrm{cfu} / \mathrm{g}^{39}$.

The production of PIF is achieved by either wet or dry processing ${ }^{40}$. The wet process involves combining all the essential ingredients with liquid skimmed milk and fat components and heating the mixture at $81^{\circ} \mathrm{C}$. In the dry process, pasteurized evaporated skimmed milk is dry blended with the balance of essential ingredients (essential fatty acids, vitamins, whey, stabilizers and emulsifiers), pasteurized at $110^{\circ} \mathrm{C}$ and spray dried ${ }^{3}$. FDA has published bulletins highlighting the dangers of bacterial contamination of enteral formula products, most of which contain PIF as the major ingredient ${ }^{41,42}$. A number of studies have not only found the contamination of $C$. sakazakii in PIF but also in the other infant or baby foods as listed in Table 2 .

\section{Recalls of C. sakazakii contaminated PIF}

It is recommended by FDA that written guidelines should be available in the event of PIF recall. There must be the notification of health care providers, a system for reporting and following up on specific formula products used, and retention of recall records ${ }^{49}$.

There have been a number of recalls of PIF due to the contamination of $C$. sakazakii as listed in Table 3.

\section{Outbreak of $\boldsymbol{C}$. sakazakii in PIF}

Since 1958, more than 70 cases have been reported with a mortality of 24 in the outbreak of $C$. sakazakii, out of these 23 cases have been reported in USA with a causality of only
3. In the last decade, twenty major outbreaks of E.sakazakii have been reported in France (2004), NewZealand (2004), Belgium (2002), and USA (2001) with a death tool of 2, 1, 1 and 1 , respectively. In the era of 1990 s, major outburst in Belgium in 1998 with 12 cases was reported with 2 causalities. But in the period of 1980 s, two main outbreaks occurred in Denmark in 1983 and Greece in 1984, 8 and 11 cases were reported with mortality of 6 and 4 , respectively ${ }^{58}$.

\section{Storage of reconstituted PIF}

According to the $\mathrm{FAO} / \mathrm{WHO}$, risk assessment for $C$. sakazakii in reconstituted PIF has increased many fold as compare to the powdered formula. The risk is increased in warmer ambient temperatures $\left(30-35^{\circ} \mathrm{C}\right)^{1}$. Reconstituted PIF in bottle for a period of time probably maximize the growth of $C$. sakazakii ${ }^{3}$. Iversen et al. have found that six clinical and food strains of C. sakazakii have grown between $6-45^{\circ} \mathrm{C}$, with maximum growth between $37-43{ }^{\circ} \mathrm{C}^{2}$. Kandhai et al. have reported that $C$. sakazakii has flourished in reconstituted PIF at $8-47{ }^{\circ} \mathrm{C}^{34}$. It has been indicated that up to $20 \%$ of household refrigerator temperatures are kept at approximate $10{ }^{\circ} \mathrm{C}$, thus providing the temperature that is suitable for the growth of C. sakazakii ${ }^{59}$.

\section{Clinical etiology and pathogenicity}

In 1992, Enterobacter species were reported as being the third most common among those recovered from the urinary and respiratory tracts, of patients in intensive care units ${ }^{60} . C$. sakazakii may have some relationship associated with several bacterial pathogens and is the most common cause of gastrointestinal disease in newborns ${ }^{31,61}$. The illness affects around $2-5 \%$ of premature neonates, leads to death in $10-55 \%$ and is characterized by ischaemia, bacterial colonization of the intestinal tract and increased levels of protein in the gastrointestinal lumen, the latter is often attributable to the consumption of $\mathrm{PIF}^{39}$. C. sakazakii produces viscous capsular material and therefore the organism could form a biofilm on feeding equipment and contact surfaces (i.e. stainless steel). A capsulated strain formed denser biofilms compared to a noncapsulated type strain ${ }^{2}$. It has been suggested that bottles and utensils used to prepare PIF should be cleaned thoroughly as soon as possible after use to eliminate or minimize the formation of biofilms, which could be the sources of infection ${ }^{3}$.

In addition, the stomach of newborns, especially of premature babies, is less acidic than that of adults, a possible important factor contributing to the survival of an infection with $C$. sakazakii in newborns. The frequency of intrinsic $C$. sakazakii contamination in PIF is of concern, even though intrinsic concentration levels of the organism appear to be typically very $l_{0}{ }^{39}$. Other reports have confirmed or implicated PIF as a source of bacteria responsible for meningitis and associated with neonatal necrotizing enterocolitis $6,30,36,62$. Contaminated PIF is one of the sources of neonatal infection that subsequently leads to high morbidity and occasional mortality in the infants $4,8,31,36,61$. Two unrelated cases involving meningitis and bacteraemia have been investigated and it was found that each victim could be linked to a particular PIF ${ }^{63}$.

Pagotto and his colleagues were the first to describe putative virulence factors for $C$. sakazakii. Using tissue cultures, some strains produced a cytotoxic effect ${ }^{64}$. The International Commission for Foods, due to the seriousness of pathologies with C. sakazakii has severed as hazard for restricted 
populations, life threatening or substantial chronic sequelae or long lasting ${ }^{65}$.

\section{Meningitis}

Meningitis is the most frequently reported condition in neonatal $C$. sakazakii infections, resulting in $90 \%$ of the cases leading to brain abscesses ${ }^{66-68}$. Meningital infection of $C$. sakazakii have been reported as arising between the fourth and fifth day after birth and can be fatal within a few hours to several days following the first clinical signs with death often occurring within hours of infection ${ }^{31,69-71}$. Seizure activity has been reported in about one-third of the cases of neonatal C. sakazakii meningitis, with physiological responses including grunting, bulging fontanelles, convulsions, twitching and an increase in cranial circumference ${ }^{31,51}$. C. sakazakii was first implicated in a case of neonatal meningitis in 1958, and since then there have been around 70 reported cases of C. sakazakii infections ${ }^{72}$.

\section{Necrotizing Enterocolitis}

A positive correlation between necrotizing enterocolitis and oral formula feeding has been suggested by various researchers ${ }^{39,58,61}$. Babies fed only on PIF rather than breast milk are 10 times more likely to contract necrotizing enterocolitis $^{73}$. Another study confirmed that in 125 infants, prior to the administration of antibiotics, Enterobactericeae species were the most prevalent bacteria, present in $29 \%$ of neonates ${ }^{74}$.

\section{High risk individuals}

Although C. sakazakii can cause illness in all age groups, infants (children $<1$ year) are at most risk with neonates and infants under two months at greatest risk. The groups of infants at greatest risk include, in particular pre-term infants, low-birth-weight $(<2.5 \mathrm{~kg})$ infants or immunocompromised infants ${ }^{1}$. The prominent predisposing factors to the onset of meningitis in neonates are premature birth, low birth weight $(<2500 \mathrm{~g})$, or prolonged rupture of membranes prior to delivery ${ }^{4,36}$. Infants of HIV-positive mothers are also at risk because they may be immunocompromised and may specifically require PIF $^{16}$. Two distinct infant risk groups for C. sakazakii infection include premature infants who develop bacteraemia after one month of age; and term infants who develop meningitis during the neonatal period. Therefore, the FAO/WHO expert working group in 2006 concluded that while infants appear to be the group at particular risk, neonates and also those of less than two months of age are at greatest risk $^{75}$.

\section{Risks and hazards control}

FDA in 2002 issued an alert to healthcare professionals about the risk associated with $C$. sakazakii infections among neonates fed with milk-based $\mathrm{PIF}^{76}$. The alert stated that a major contribution to the avoidance of $C$. sakazakii infections in premature babies and neonates is the prevention of contamination of PIF during production and bottle preparation $^{33}$. Ingredients such as raw milk might be contained with Enterobactericeae, and these organisms are eliminated following pasteurization, whereas dry ingredients, added post-pasteurization must be free of bacterial and other types of contamination. The manufacturing plant design should specially separate different processing areas (essentially dry and wet processing), and frequent cleaning regimes should be implemented to minimize the persistence of pathogens in the manufacturing process and environment.
The dry area of the manufacturing facility is of critical importance, so hygienic zoning should be considered as a means of controlling the unwanted entry of contaminants ${ }^{2}$. The hygienic zoning practice encompasses safety management strategies that incorporate regular inspections of the lining of the spray-drying chamber; and associated equipment to detect any structural flaws in the process. Additionally, all external air supplies should be filtered, and internal air systems, preferably under positive pressure, should be designed to minimize the circulation of powder dust. Another important preventive measure is the maintenance of a low-moisture environment in postpasteurization. The practice should include the use of dry cleaning procedures such as vacuum cleaners, coarse brushes, scrapers and the avoidance of wet cleaning methods. Packing areas should be separated from the process area and measures implemented to minimize exposure of the finished product to the surrounding environment. Continuous monitoring is essential as a validation exercise to evaluate the effectiveness of each control measure. C. sakazakii is found commonly in the processing environment, and therefore, even the strictest hygienic practices will not achieve total elimination, resulting in eventual low level sporadic contamination of finished product. It is therefore important to establish control measures during reconstitution, followed by prompt consumption of the milk ${ }^{2}$.

It has been noted that problems associated with the cleaning methods include a higher probability of post-processing contamination, ingredient mixing difficulties and ingredient separation, including lactose segregation ${ }^{9,39}$. It is often the case that dry and wet processing procedures are combined by adding the more soluble ingredients during the liquid phase and the less soluble ones into the spray-dried powder matrix $^{8,71}$. Factories differ in many ways (e.g., age, building materials, design and cleanability) that would influence the level of efficiency in controlling the microbial ecology therein. Hence, the risk of formula contamination can be expected to be a function of the particular factory environment rather than solely the manufacturing processes. The rate of inactivation of C. sakazakii in PIF held at room temperature has been studied by Edelson-Mammel and Buchanan $^{77}$. Although one isolate of $C$. sakazakii has been cultured from one sample of PIF, this might have been due to an unequal distribution in the powder or its presence at such a low concentration that it escaped detection by conventional methods. Large amounts of powdered substitutes for breast milk should be obtained from different sources to be analyzed for the presence of this bacterium ${ }^{78}$.

It has been suggested that thermal treatment of rehydrated PIF may be a practical way of minimizing neonatal risk to $C$. sakazakii infection ${ }^{79-81}$. Simmons et al. has recommended using refrigeration and limiting hang time to prevent or retard the growth of $C$. sakazakii ${ }^{5}$. Jaspar et al. have also recommended storing rehydrated formula at refrigeration temperatures as well as heating the formula in a microwave oven just prior to feeding ${ }^{79}$. Others have echoed the last two suggestions and have cautioned that bottle warmers may pose a risk of prolonged exposure to temperatures at which $C$. sakazakii can rapidly grow ${ }^{30}$.

PIF should be reconstituted at $70{ }^{\circ} \mathrm{C}$ for the inactivation of bacterial growth and if not consumed completely then it should be refrigerated. C. sakazakii strains did not grow at 4 ${ }^{\circ} \mathrm{C}$ and began to die off during storage at this temperature. $C$. sakazakii was found to be more thermo-tolerant than most other Enterobacteriaceae which may contribute to its 
survival of heat treatments, and subsequent presence in desiccated products. The lowest temperature of growth is 5 ${ }^{\circ} \mathrm{C}$ and therefore potentially the organism can grow during refrigerated storage ${ }^{80}$. When PIF is reconstituted with $\geq 70{ }^{\circ} \mathrm{C}$ water, the risk is dramatically reduced, and this risk reduction remains valid for feeding times of two hours. This finding has practical implications for the reduction of risk of $C$. sakazakii infection for slow-feeding infants and for infants in warm climates where ambient room temperature may be around $35{ }^{\circ} \mathrm{C}^{81}$. It has been recommended that the formula should not be held at room temperature for more than two hours, even if water at no less than $70{ }^{\circ} \mathrm{C}$ is used to reconstitute $\mathrm{PIF}^{82}$. This is because the feed may have become contaminated during preparation, or harmful bacteria may have been introduced into the cup or feeding bottle from the infant's mouth. Also, hot water $\left(70{ }^{\circ} \mathrm{C}\right)$ may have activated bacterial spores of harmful bacteria in the formula. Lihono et al. have examined the use of probiotic cultures to control the growth of $C$. sakazakii in rehydrated PIF at 30 and $35^{\circ} \mathrm{C}^{83}$. Holding prepared feeds above refrigeration temperature for extended periods provides the opportunity for the growth of C. sakazakii ${ }^{1}$.

Table 1: Biochemical Identification Test of Cronobacter sakazakii

\begin{tabular}{|c|c|}
\hline Biochemical Test & Result \\
\hline Tween 80 esterase & Positive \\
\hline Phosphoamidase & Positive \\
\hline$\alpha$-glycosidase & Positive \\
\hline Yellow pigmentation on TSA & Positive \\
\hline D-sorbitol fermentation & Negative \\
\hline
\end{tabular}

Table 2: Contamination of Cronobacter sakazakii in Infant/Baby Food and Milk

\begin{tabular}{|c|c|c|c|c|}
\hline Sample & Sample Size & Positive Sample & Percentage & Reference \\
\hline Pediatric Infant Formula & 141 & 21 & $14.9 \%$ & 8 \\
\hline Pediatric Infant Formula & 120 & 8 & $6.7 \%$ & 9 \\
\hline Pediatric Infant Formula & 82 & 2 & $2.4 \%$ & 43 \\
\hline Milk Formula & 72 & 3 & $4.2 \%$ & 43 \\
\hline Infant Food & 49 & 5 & $10.2 \%$ & 43 \\
\hline Pediatric Infant Formula & 124 & 3 & $2.4 \%$ & 44 \\
\hline Pediatric Infant Formula & 35 & 2 & $5.7 \%$ & 45 \\
\hline Pediatric Infant Formula & 58 & 8 & $13.8 \%$ & 46 \\
\hline Milk Formula & 170 & 7 & $4.1 \%$ & 47 \\
\hline Pediatric Infant Formula & 40 & 1 & $2.5 \%$ & 47 \\
\hline Pediatric Infant Formula & 8 & 2 & $25 \%$ & 48 \\
\hline Infant Food & 15 & 2 & $13.3 \%$ & 48 \\
\hline
\end{tabular}

Table 3: Recalls of Cronobacter sakazakii contaminated Pediatric infant formula

\begin{tabular}{|c|c|c|}
\hline Year Of Recall & Region/ Country/ Product & Reference \\
\hline 1998 & $\begin{array}{c}\text { Nestle Beba } 1 \text { was manufactured by Nestle Germany Kapeln (Belgium and Switzerland, but is also } \\
\text { being recalled from Luxembourg) }\end{array}$ & 50 \\
\hline 2001 & Tennesseein (USA) & 51 \\
\hline 2002 & Mead Johnson Nutritionals (batch BMC17 of Portagen) & 52 \\
\hline 2002 & Store brand powdered formula Contaminated with C. sakazakii & 53 \\
\hline 2002 & Wyeth Nutritionals Inc., Georgia, Vermont & 54 \\
\hline 2003 & (Mead Johnson) EnfaCare Lipil & 55 \\
\hline 2004. & Mead Johnson Nutritionals (Pregestimil in December) & 56 \\
\hline 2011 & Wall-Mart is pulling Enfamil infant formula (Missouri) & 57 \\
\hline
\end{tabular}

\section{CONCLUSION}

Cronobacter sakazakii is one of the most lethal contaminant found in pediatric food and/or milk formula. It is a motile, Gram-negative, non-sporing yellow pigmented rod belonging to Enterobacteriaceae family. $C$. sakazakii is found everywhere in air, soil, floor drains, room heater, cleaninplace valve, and floor. It has also been isolated in hospitals, clinical materials, and cutting fluids. C. sakazakii has also been found in throat, blood, sputum, nose, stool, gut, skin, bone marrow, eye, ear, and breast abscess. Because of its pathogenicity and virulence, it mainly causes necrotizing enterocolitis, meningitis, bacteraemia and septicemia. It may adhere to latex, silicon, polycarbonate, and stainless steel and form biofilm. Moreover, FDA, Health Canada, FAO/WHO, and CDC forcefully advocate mother-feed over bottle-feed to avoid the possible life threatening illness to neonates and infants caused by the contamination of C. sakazakii.

\section{REFERENCES}

1. Iversen C, Lehner A, Mullane N, Bidlas E, Cleenwerck I, Marugg J, et al. The taxonomy of Enterobacter sakazakii: proposal of a new genus Cronobacter gen. nov. and descriptions of Cronobacter sakazakii comb. nov. Cronobacter sakazakii subsp. sakazakii, comb. nov., Cronobacter sakazakii subsp. malonaticus subsp. nov., Cronobacter turicensis sp. nov., Cronobacter muytjensii sp. nov., Cronobacter dublinensis sp. nov. and Cronobacter genomospecies 1. BMC Evol Biol 2007; 7: 64. http://dx.doi.org/10.1186/1471-2148-7-64

PMid: 17439656 PMCid:1868726

2. Iversen C, Lane M, Forsythe SJ. The growth profile, thermotolerance and biofilm formation of Enterobacter sakazakii grown in infant formula milk. Lett Appl Microbiol 2004; 38: 378-82. http://dx.doi.org/10.1111 /j.1472-765X.2004.01507.x PMid:15059207

3. Gurtler JB, Kornacki JL, Beuchat LR. Enterobacter sakazakii: a coliform of increased concern to infant health. Int J Food Microbiol 2005; 104 Suppl 1: 1-34. http://dx.doi.org/10.1016/j.ijfoodmicro.2005.02.013 PMid:16039742

4. Willis J, Robinson JE. Enterobacter sakazakii meningitis in neonates. Pediatr Infect Dis J 1988; 7: 196-9. http://dx.doi.org/10.1097/00006454198803000-00012 PMid:3282215

5. Simmons BP, Gelfand MS, Haas M, Metts L, Ferguson J. Enterobacter sakazakii infections in neonates associated with intrinsic contamination of a powdered infant formula. Infect Control Hosp Epidemiol 1989; 10: 398-401. http://dx.doi.org/10.1086/646060 PMid:2794464

6. Bar-Oz B, Preminger A, Peleg O, Block C, Arad I. Enterobacter sakazakii infection in the newborn. Acta Paediatrica 2001; 90: 356-8 http://dx.doi.org/10.1080/080352501300067857 PMid:11332182 
7. Heuvelink AE, Ahmed M, Kodde FD, Zwartkruis-Nahuis JTM, de Boer E. Enterobacter sakazakii in melkpoeder. De Ware (n) Chemicus 2002; 32:17-30.

8. Muytjens HL, Roelofs-Willemse H, Jaspar GHJ. Quality of powdered substitutes for breast milk with regard to members of the family Enterobacteriaceae. J Clin Microbiol 1988; 26: 743-6. PMid:3284901 PMCid:266435

9. Nazarowec-White M, Farber JM. Incidence, survival, and growth of Enterobacter sakazakii in infant formula. J Food Prot 1997; 60: 226-30.

10. Naqvi SH, Maxwell MA, Dunkle LM. Cefotaxime therapy of neonatal Gram-negative bacillary meningitis. Pediatr Infect Dis J 1985; 4: 499502. http://dx.doi.org/10.1097/00006454-198509000-00012

11. Monroe PW, Tift WL. Bacteremia associated with Enterobacter sakazakii (yellow-pigmented Enterobacter cloacae). J Clin Microbiol 1979; 10: 850-851. PMid:521484 PMCid:273282

12. Steere AC, Aber RC, Warford LR, Murphy KE, Feeley JC, Hayes PS, Wilkinson HW, Facklam RR. Possible nosocomial transmission of group B streptococci in a newborn nursery. J Pediatr 1975; 87: 784-7. http://dx.doi.org/10.1016/S0022-3476(75)80311-8

13. Tift WL. Group B streptococcal infections in the neonate. J Med Assoc Ga 1977; 66: 703-5. PMid:333052

14. Steigerwalt AG, Fanning GR, Fife-Asbury MA, Brenner DJ. DNA relatedness among species of Enterobacter and Serratia. Canad J Microbiol 1976; 22: 121-37. http://dx.doi.org/10.1139/m76-018 PMid: 1260520

15. Brenner DJ, Farmer JJ, Hickmann FW, Asbury MA, Steigerwalt AG. Taxonomic and Nomenclature Changes in Enterobacteriaceae. US Department of Health, Education and Welfare, Centers for Disease Control and Prevention. Atlanta, GA: Public Health Service; 1977.

16. Mullane NR, Drudy D, Whyte P, O'Mahony M, Scannell AGM, Wall $\mathrm{PG}$ et al. Enterobacter sakazakii: biological properties and significance in dried infant milk formula (IMF) powder. Int J Dairy Technol 2006; 59 Suppl 2: 102-11. http://dx.doi.org/10.1111/j.1471-0307.2006.00252.x

17. Bej AK. Molecular based methods for the detection of microbial pathogens in the environment. J Microbiol Methods 2003; 53:139-40. http://dx.doi.org/10.1016/S0167-7012(03)00035-6

18. Wang M, Cao B, Gao Q, Sun Y, Liu P, Feng L, Wang L. Detection of Enterobacter sakazakii and Other Pathogens Associated with Infant Formula Powder by Use of a DNA Microarray. J Clin Microbiol 2009; 47 Suppl 10: 3178-84 http://dx.doi.org/10.1128/JCM.00366-09 PMid: 19641057 PMCid:2756907

19. FAO [Food and Agriculture Organization of the United Nations]/WHO [World Health Organization]. Enterobacter sakazakii and other microorganisms in powdered infant formula. Microbiological Risk Assessment Series, No. 6; 2004

20. Van Os M, Van Wikeselaar PG, Spoelstra SF. Formation of biogenic amines in well fermented grass silages. J Agric Sci Cambridge 1996; 127: 97 - 107. http://dx.doi.org/10.1017/S0021859600077418

21. Masaki H, Asoh N, Tao M, Ikeda H, Degawa S, Matsumoto K, et al. Detection of Gram-negative bacteria in patients and hospital environments at a room in geriatric wards under the infections control against MRSA. J Jpn Assoc Infect Dis 2001; 75: 144-50.

22. Janicka G, Kania I, Ulatowska B, Krusznska E, Wojda M. The occurrence of the Enterobacter genus rods in clinical material and material taken from hospital environment. Wiadomosci Lekaarskie 1999; 52: 554-8.

23. Tuncer I and Ozsan K. Biochemical typing of Enterobacter isolated from several clinical materials. Mikrobiyol Bul 1988; 22: 105-12. PMid:3078792

24. Gakuya FM, Kyule MN, Gathura PB, Kariuki S. Antimicrobial resistance of bacterial organisms isolated from rats. East Afr Med J 2001; 78: 646-9. http://dx.doi.org/10.4314/eamj.v78i12.8934 PMid: 12199446

25. Neelam M, Nawaz Z, Riazuddin S. Hydrocarbon biodegradation biochemical characterization of bacteria isolated from local soils. Pak J Sci Ind Res 1987; 30: 382-5.

26. Emilani F, Lajmanovich R, Gonzales SM. Escherichia coli: biochemical phenotype diversity in fresh waters (Santa Fe Province, Argentina). Rev Argent Microbiol 2001; 33: 65-74.

27. Espeland EM, Wetzel RG. Complexation, stabilization, and UV photolysis of extracellular and surface-bound glucosidase and alkaline phosphatase: implications for biofilm microbiota. Microbial Ecol 2001; 42:572-85.http://dx.doi.org/10.1007/s00248-001-1023-7 PMid: 12024240

28. Assadi MM, Mathur RP. Application of an HPLC system in the analysis of biodegraded crude oil compounds. J Liq Chromatogr 1991; 14: 3623 9. http://dx.doi.org/10.1080/01483919108049416

29. Suliman SMA, Abubakr MI, Mirghani EF. Microbial contamination of cutting fluids and associated hazards. Tribol Int 1988; 30: 737-57.
30. Muytjens HL and Kollee LAA. Enterobacter sakazakii meningitis in neonates: causative role in formula. J Pedia Infect Dis 1990; 9: 372-3. http://dx.doi.org/10.1097/00006454-199005000-00016

31. Muytjens HL, Zanen HC, Sonderkamp HJ, Kollee LA, Wachsmuth IK, Farmer JJ. Analysis of eight cases of neonatal meningitis and sepsis due to Enterobacter sakazakii. J Clin Microbiol 1983; 18: 115-20. PMid:6885983 PMCid:270753

32. Krieg NR, Holt JG. Bergy's Manual of Systematic Bacteriology. Vol. 1., Baltimore, Williams and Wilkins Press: 1984; p. 408-20, 466, 467.

33. Aigbekaen BO, Oshoma CE. Isolation of Enterobacter sakazakii from Powdered Foods Locally Consumed in Nigeria. Pak J Nutri 2010; 9 Suppl 7: 659-63. http://dx.doi.org/10.3923/pjn.2010.659.663

34. Kandhai MC, Reij MW, and Gorris LGM. Occurrence of Enterobacter sakazakii in food production environments and households. Lancet 2004; 363: 39-40. http://dx.doi.org/10.1016/S0140-6736(03)15169-0

35. Jung MK and Park JH. Prevalence and thermal stability of Enterobacter sakazakii from unprocessed ready-to-eat agricultural products and powdered infant formulas. Food Sci Biotechnol 2006; 15: 152-7.

36. Biering G, Karlsson S, Clark NC, Jonsdottir KE, Ludvigsson P and Steingrimsson $\mathrm{O}$. Three cases of neonatal meningitis caused by Enterobacter sakazakii in powdered milk. J Clin Microbiol 1989; 27: 2054-6. PMid:2778070 PMCid:267737

37. Van Acher J, de Smet F, Muyldermans G, Bougatef A, Naessens A, Lauwers S. Outbreak of necrotizing enterocolitis associated with Enterobacter sakazakii in powdered milk formula. J Clin Microbiol 2001; 39: 293-7. http://dx.doi.org/10.1128/JCM.39.1.293-297.2001 PMid:11136786 PMCid:87717

38. Himelright I, Harris E, Lorch V, Anderson M. Enterobacter sakazakii infections associated with the use of powdered infant formula Tennessee, 2001. J Amr Med Assoc 2002; 287: 2204-5. http://dx.doi.org $/ 10.1001 /$ jama.287.17.2204

39. FAO [Food and Agriculture Organization of the United Nations]/WHO [World Health Organization]. Principles and guidelines for incorporating microbiological risk assessment in the development of food safety standards Report of a joint FAO/WHO consultation, Kiel, Germany; 2002.

40. Caric M. Concentrated and dried dairy products. In: Hui YH (Ed.), Dairy Science and Technology Handbook, Vol. 2. New York: VCH Publishers; 1993.

41. U.S. Food and Drug Administration. FDA warns about possible Enterobacter sakazakii infections in hospitalized newborns fed powdered infant formulae. FDA Talk Paper; 2002.

42. U.S. Food and Drug Administration. Bacterial contamination of enteral formula products. FDA Talk Paper; 1988

43. Iversen C, Forsythe S. Risk profile of Enterobacter sakazakii, an emergent pathogen associated with infant milk formula. Tren Food Sci Technol 2003; 14: 443-54. http://dx.doi.org/10.1016/S09242244(03)00155-9

44. Ghodeker DR, Srinivasan RA, Nambudripad VKN. Coliform bacteria in dried milks. J Dairy Sci 1980; 33: 490-6.

45. El-Sharoud WM, O Brien S, Negredo, C, Iversen C, Fanning S, Healy B. Characterization of Cronobacter recovered from dried milk and related products. BMC Microbiol 2009; 9: 24. http://dx.doi.org/ 10.1186/1471-2180-9-24PMid:19187534 PMCid:2640398

46. Leuscher RGK, Baird F, Donald B, Cox LJ. A medium for the presumptive detection of Enterobacter sakazakii in infant formula. Food Microbiol 2004; 21: 527- $33 . \quad$ http://dx.doi.org/10.1016/ j.fm.2003.12.002

47. Heuvelink AE, Kodde FD, Zwartkruis-Nahuis JTM, de Boer E. Enterobacter sakazakii in Melkpoeder. Project number OT 0110, Keuringsdienst van Waren Oost; 2001.

48. Shaker R, Osaili T, Al-Omary W, Jaradat Z, Al-Zuby M. Isolation of Enterobacter sakazakii and other Enterobacter spp. from food and food production environments. Food Control 2007; 18: 1241-5. http://dx.doi.org/10.1016/j.foodcont.2006.07.020

49. U.S. Food and Drug Administration, Regulation-Registrar Crop. Portagen powder recall. 2002 [cited 201308 February]. Available from http://www.fda.gov/oc/po/firmrecalls/meadjohnson03 02.html

50. Infact Canada. 2002 [cited 201308 February]. Available from http://www.infactcanada.ca/how safe are infant formulas.htm

51. Weir E. Powdered infant formula and fatal infection with Enterobacter sakazakii. Can Med Assoc J 2002; 166: 1570.

52. Baker RD. Infant formula safety (Commentary). Pediatrics 2002; 110 : 833-5. http://dx.doi.org/10.1542/peds.110.4.833 PMid: 12359804

53. Centers for Disease Control and Prevention (CDC). Enterobacter sakazakii infections associated with the use of powdered infant formula - Tennessee, 2001. Morb Mortal Wkly Rep 2002; 51 Suppl 14: 298300 .

54. FDA Recall Baby Formula. [Updated 2008, 16 June, cited 2013, 10 February]. Available from ]http://www.cafemom.com/journals/ read $/ 1052726 / \% 3 \mathrm{Ca} \% 20 \mathrm{href}$ 
55. Dairy News. FDA alerts public regarding recall of powdered infant formula. 2002 [cited 2013, 10 February] Available from http://www.nda.da.gov.ph/na60.htm

56. Food Safety Authority of Ireland. Pregestimil infant formula recall. [cited 2013, 08 February] Available from http://www.fsai.ie/ alerts/archive /fa20050120.asp

57. Walmart recalls Enfamil infant formula after baby's death. [Updated 2011, 22 December, cited 2013, 10 February] http:// www.examiner.com/article/walmart-recalls-enfamil-infant-formulaafter-baby-s-death

58. Drudy D, Mullane NR, Quinn T, Wall PG, Fanning S. Enterobacter sakazakii: an emerging pathogen in powdered infant formula. Clin Infect Dis 2006; 42 Suppl 7: 996-1002. http://dx.doi.org/10.1086/501019 PMid: 16511766

59. Daniels RW. Applying HACCP to new-generation refrigerated foods and beyond. Food Technol 1991; 45 Suppl. 66: 122-4.

60. Van Garde SJ, Woodburn M. Food discard practices of households. J Am Diet Assoc 1987; 87: 322-9. PMid:3819252

61. Jarvis WR, Martone WJ. Predominant pathogens in hospital infections. J Antimicrob Chemother 1992; 29 Suppl. A: 19-24.

62. Van Acker J, de Smet F, Muyldermans G, Bougatef A, Naessens A, Lauwers S. Outbreak of necrotizing enterocolitis associated with Enterobacter sakazakii in powdered milk formula. J Clin Microbiol 2001; 39: 293-7. http://dx.doi.org/10.1128/JCM.39.1.293-297.2001 PMid: 11136786 PMCid:87717

63. Clark NC, Hill BC, O Hara CM, Steingrimsson O, Cooksey RC. Epidemiologic typing of Enterobacter sakazakii in two neonatal nosocomial outbreaks. Diag Microbiol Infect Dis 1990; 13: 467-72. http://dx.doi.org/10.1016/0732-8893(90)90078-A

64. Pagotto FJ, Nazarowec-White M, Bidawid S, Farber JM. Enterobacter sakazakii: infectivity and enterotoxin production in vitro and in vivo. J Food Protec 2003 66: 370-5. PMid:12636287

65. International Commission on Microbiological Specification for Foods (ICMSF). Microbiological Testing in Food Safety Management. Vol. 7. New York: Academic/Plenum Publisher; 2002.

66. Burdette JH, Santos C. Enterobacter sakazakii brain abscess in the neonate: the importance of neuroradiologic imaging. Pediatr Radiol $2000 ; \quad 30$ : 33-4. http://dx.doi.org/10.1007/s002470050009 PMid: 10663506

67. Gallagher PG, Ball WS. Cerebral infarctions due to CNS infection with Enterobacter sakazakii. Pediatr Radiol 1991; 21: 135-6. http://dx.doi.org/10.1007/BF02015629 PMid:2027718

68. Kline MW. Pathogenesis of brain abscess caused by Citrobacter or Enterobacter sakazakii. Pediatr Infect Dis J 1988; 7: 891-2. http://dx.doi.org/10.1097/00006454-198807120-00021

69. Adamson DH, Rogers JR. Enterobacter sakazakii meningitis with sepsis. Clin Microbiol News 1981; 3: 19-20. http://dx.doi.org/10.1016/S01964399(81)80039-6

70. Arseni A, Malamou-Ladas E, Koutsia C, Xanthou M, Trikka E. Outbreak of colonization of neonates with Enterobacter sakazakii. J Hosp Infect 1987; 9: 143-50. http://dx.doi.org/10.1016/01956701(87)90052-1

71. Kleiman MB, Allen SD, Neal P, Reynolds J. Meningoencephalitis and compartmentalization of the cerebral ventricles caused by Enterobacter $\begin{array}{llllll}\text { sakazakii J Clin Microbiol 1981; } 14: 352-4 & \text { PMid:7287892 }\end{array}$ PMCid: 271970

72. Nazarowec-White M, Farber JM. Enterobacter sakazakii: a review. Int J Food Microbiol 1997; 34: 103- 13. http://dx.doi.org/10.1016/S01681605(96)01172-5

73. Kosloske AM. Pathogenesis and prevention of necrotizing enterocolitis: a hypothesis based on personal observation and a review of the literature. Pediatrics 1984; 74: 1086-92. PMid:6390330

74. Chan KL, Saing H, Yung RW, Yeung YP, Tsoi NS. A study of preantibiotic bacteriology in 125 patients with necrotizing enterocolitis. Acta Paediat 1994; 396: 45-8. http://dx.doi.org/10.1111/j.16512227.1994.tb13242.x

75. World Health Organization. Enterobacter sakazakii and other microorganisms in powdered infant formula: meeting report. Microbiological risk assessment series, no. 6. 2004. [cited 2013, 08 February]. Available from http://www.who.int/foodsafety/ publications/micro/mra6/en

76. FDA (Food and Drug Administration). Isolation and enumeration of Enterobacter sakazakii from dehydrated powdered infant formula. USFDA Centre for Food Safety and Applied Nutrition. 2002.

77. Edelson-Mammel SG, Buchanan RL. Long-term survival of Enterobacter sakazakii in powdered infant formula. Abstract \#P169, Program and Abstract Book, 91st Annu. Mtg., Int. Assn. Food Prot., Phoenix, AZ, 8-11 August; 2004. p. 107.

78. Bushra J Al-Timimi. Antimicrobial resistance of bacteria isolated from powdered infant formulas (PIF). Med J Babyl 2007; 4: 251-62

79. Jaspar AHJ, Mutyjens HL, Kolee LAA. Neonatal meningitis caused by E. sakazakii: Milk powder is not sterile and bacteria like milk too. Tijdschr Kindergenee Skd 1990; 58: 151-5. PMid:2247876

80. Nazarowec-White M, Farber JM, Cordier JL, van Schothorst M. Enterobacter sakazakii. In: Miliotis, MD, Bier JW (Eds.), International Handbook of Foodborne Pathogens. New York: Marcel Dekker; 2003. p. 407-413.

81. Kandhai MC, Reij MW, cGrognou C, van Schothorst M, Gorris LGM, Zwietering MH. Effects of Preculturing Conditions on Lag Time and Specific Growth Rate of Enterobacter sakazakii in Reconstituted Powdered Infant Formula. Appl Envir Microbiol 2006; 72 Suppl 4: $2721-9$. PMid: 16597976 PMCid:1448981

82. FAO [Food and Agriculture Organization of the United Nations]/WHO [World Health Organization]. 2006. Enterobacter sakazakii and Salmonella in powdered infant formula. Meeting Report. Joint FAO/WHO Technical Meeting on Enterobacter sakazakii and Salmonella Powdered Infant Formula, [FAO/WHO] Microbiological Risk Assessment Series, No. 10. Rome, Italy, 16-20 January; 2006.

83. Lihono MA, Bisha B, Mendonca A, Bankston L, Boyston T. Fate of Enterobacter sakazakii ATCC 12868 in temperature- abused reconstituted infant formula containing probiotic cultures. Abstract \#P135, Program and Abstract Book, 91st Annu. Mtg., Int. Assn. Food Prot., Phoenix, AZ 8-11 August; 2004. p. 96.

Cite this article as:

Adeel Arsalan, Zubair Anwar, Iqbal Ahmad, Zufi Shad, Sadia Ahmed. Cronobacter sakazakii: An emerging contaminant in pediatric infant milk formula. Int. Res. J. Pharm. 2013; 4(4):17-22 